\title{
Continuous usage intention to e-transaction cards in wholesale markets of agriproducts: empirical evidence from China
}

\author{
Xuechao Sui $^{{ }^{*}}$ (10) and Xianhui Geng ${ }^{2}$
}

\begin{abstract}
Generalizing the e-transaction services in wholesale markets of agriproducts is seen as a way for the government in China to enhance its information services capabilities. These services could also facilitate the transactions of traders. We find that traders are reluctant to use e-transaction cards although they have physical access. This paper identifies factors influencing traders' continuous usage intention to e-transaction cards in wholesale markets of agriproducts in China. Data were collected from 204 respondents through a self-administered survey completed by traders and analyzed by structural equation modeling (SEM). The results explore that perceived ease of use (PEOU), perceived usefulness (PU) and perceived privacy security (PPS) directly and positively affect traders' continuous usage intention. It is also demonstrated that both PEOU and perceived transaction security indirectly and positively affect continuous usage intention through PU. This research provides practical guidelines for decision makers to increase traders' intention to e-transaction cards.
\end{abstract}

Keywords: Wholesale markets of agriproducts, E-transaction, Continuous usage intention, China JEL Classification: O33, Q13, Q16

\section{Introduction}

Generalizing the e-transaction services in wholesale markets of agriproducts is seen as a way for the government in China to enhance its information services capabilities. ${ }^{1}$ These services can be used to collect accurate transaction data (i.e., data on the provenance, destination, price, quantity and payments) from wholesale markets in a timely manner and at a low cost (see footnote1). ${ }^{2}$ Thus, the government could provide market information and advisory agricultural information to farmers and traders by analyzing the transaction data (see footnotes 1 , 2 ). Traders could benefit from a reduction in transaction costs and an increase in the convenience of using e-transaction cards. We find that traders are reluctant to use

\footnotetext{
*Correspondence: xcsui@hfut.edu.cn

${ }^{1}$ School of Economics, Hefei University of Technology, No. 485 Danxia

Road, Hefei 230601, Anhui, People's Republic of China

Full list of author information is available at the end of the article
}

e-transaction cards although they have physical access (see footnotes 1,2) [1]. This suggests need for examining factors affecting traders' continuous usage intention to e-transaction cards in wholesale markets of agriproducts in China.

The agricultural supply chain in China involves millions of smallholder farmers, traders, and retailers. The traders collect agriproducts from smallholder farmers across the country and sell them to retailers in wholesale markets of agriproducts, which often use cash transactions without long-term contracts [2, 3]. According to statistics published by China's government, there are currently approximately 4,500 wholesale markets of agriproducts (see footnote 1), and the proportion of agriproducts circulating through wholesale markets has reached 70\% [4]. However, many agents involved in distribution are often

\footnotetext{
${ }^{1}$ Source: http://www.moa.gov.cn/nybgb/2015/liu/201712/t20171219_61038 57.htm (in Chinese).

${ }^{2}$ Source: http://www.mofcom.gov.cn/article/ae/ai/201508/2015080109 7398.shtml (in Chinese).
} 
faced with poor information transmission along the agricultural supply chain [3]. The lack of market information often restrains individual farmers from making effective production quantity decisions, which leads to stage-bystage oversupply and undersupply of fresh agriproducts and drastic fluctuations in prices in China, all of which adversely affect farmers' earnings and livelihoods [5].

The Chinese government has attempted to overcome these challenges by promoting e-transaction services in wholesale markets of agriproducts. In 2013, the Ministry of Commerce of China proposed promoting the penetration of e-transaction in wholesale markets of agriproducts to reach $60 \%$ coverage in $3-5$ years. ${ }^{3}$ Over the past decade, despite the large amount of government funds used for e-transaction systems in wholesale markets of agriproducts, the latest reports from the Ministry of Agriculture of China show that traders, although they have physical access, are reluctant to use e-transaction services, resulting in a low levels of actual usage of e-transaction systems and a significant waste of the financial resources of the government (see footnote 1).

Previous researchers have conducted comparable studies in electronical financial transactions from the customers' perspective [6]. In particular, the factors influencing customers' intentions or the adoption of e-payments have been extensively studied in past years, and examples of e-payments include mobile payments [7-10], Internet banking [11-13], e-payments in public transportation [14, 15], online payment in e-commerce [16-18] and e-payment cards in the hospital industry [19, 20]. However, few studies have examined e-transaction in the wholesale markets of agriproducts in China. One of the reasons that users of e-payments hesitate of using the web for financial transactions is that their users are afraid of risk and security issues [21, 22]. Previous empirical studies confirmed that there is a significant relationship between the security concerns and acceptance of e-payment [8, 10, 12, 23]. A great deal of prior empirical researches has focused on overall perceived security (PS, or overall PR) $[8,10,12,23]$, and that these studies do not accurately and completely assess the relevant dimensions of security concerns [24].

This paper employs technology acceptance model (TAM) as the theoretical basis, combining perceived transaction security and perceived privacy security as additional constructs to explain the factors affecting traders' continuous usage intention to e-transaction cards in wholesale markets of agriproducts in China. With this in mind, an empirical study using SEM based on actual data is conducted to investigate the factors from the traders' perspective. A structured questionnaire is used to collect data from 204 traders in the Zhougudui wholesale market of agriproducts (ZWMA) in Hefei, the trading volume of which ranks in the top 20 in China. The contributions of this paper are highlighted below:

1. This study extends research on e-payment usage intention or adoption to a new context: e-transaction in agricultural wholesale markets in China. The study has important practical implications, which could help the Chinese government promote the penetration of e-transaction in agricultural wholesale markets more effectively.

2. A host of prior studies focuses on customers' (or consumers) intention. Different from the prior studies, this study contributes to better understand about the intention from vendors' perspective.

3. The study takes TAM as the theoretical basis and introduces security-based constructs to the model. In contrast to previous studies, this paper divides PS into two dimensions, perceived transaction security (PTS) and perceived privacy security (PPS).

In the next section, we review the literature related to the usage intention or adoption of e-payment. "E-transaction services in ZWMA at a glance" section reviews e-transaction services provided in the ZWMA in Hefei, China. "Theoretical background and hypothesis" section presents the theoretical background of our research model and therefore establishes seven hypotheses. "Methods" section introduces the methodology and data collection processes. "Data analysis and results" section provides the empirical results, and finally, the conclusions and practical implications of the study are given in "Conclusion" section.

\section{Literature review}

The e-transaction service provided in wholesale markets of agriproducts is somewhat analogous to a method of e-payment, by which the transactions in wholesale markets can be settled via electronic transfer made by the payer to the payee. ${ }^{4}$ Previous studies have explained the usage intention, initial adoption or continuous usage intention of e-payment across diversity of scenarios. For example, mobile payment has been one of the most extensively researched areas in the domain of e-payment adoption research [7-10]. With the increasing applications of electronic banking services in the
${ }^{3}$ Source: http://www.mofcom.gov.cn/article/b/d/201304/20130400108025. shtml (in Chinese).
${ }^{4}$ See in "E-transaction services in ZWMA at a glanceE-transaction services in ZWMA at a glance" section. 
present commercial scenario, Internet banking adoption is another research focus [11-13]. Previous researchers also conducted comparable studies based on other e-payment adoption scenarios, such as e-payment in public transportation [14, 15], online payment in e-commerce [16-18] and e-payment cards in the hospital industry [19, 20]. However, few studies have examined e-transaction in the agricultural wholesale markets in China.

Many independent variables from several dominant theories were employed to explain users' intention or adoption of e-payment in existing studies. Unsurprisingly, the most influential independent variable was PU, followed by PEOU $[19,25]$. These two variables are from the widely known TAM proposed by [26]. According to [26], PEOU reflects a person's perception that using a new technology is effortless or simply easy to do, PU is defined as the grade at which a person believes that usage of a new technology can contribute to his job performance. The effect of additional factors similar to PU and PEOU in other theories has also been tested. For instance, effort expectancy (EE, similar to PEOU) and performance expectancy (PE, similar to $\mathrm{PU}$ ) from the unified theory of acceptance and use of technology (UTAUT) ranked second in explaining usage intention or adoption of e-payment $[9,27,28]$. Relative advantage (RA, similar to PU), complexity and compatibility, which are factors of the diffusion of innovations (DOI), have also been tested by many e-payment adoption studies [29-31]. Some studies further extended the original models by adding other independent variables to accommodate the peculiarities of specific contexts. The key success factors reported in the literature can be categorized as attributes of e-payment, individual attributes of end users and social attributes of end users [12, 32-34].

In addition to perceived benefits (e.g., PU and PEOU), innovations are usually associated with risk [35]. By expanding the TAM and DOI [7] empirical results found that security concerns and privacy concerns have a significant impact on user's perceived risk (PR), and eventually, PR negatively affects the usage intention to m-payments. In addition to [7] studies, such as [9, 10, 34], and [12] found PR as the major inhibitor of e-payment adoption. Schierz et al. [8] conducted an empirical study by expanding the TAM and DOI and found that perceived security (including privacy security) positively affected the usage attitude of m-payment services. Previous empirical studies confirmed that there is a significant relationship between the security and acceptance of e-payment [23, 32, 33]. A great deal of prior empirical researches has focused on overall perceived security (or overall PR) $[8,10,12,23]$, and that these studies do not accurately and completely assess the relevant dimensions of security concerns [24]. Some studies have focused specifically on the determinants of two important factors-security and trust, as well as the impacts of security and trust on the adoption of e-payment [11, 36, 37]. Several previous empirical studies employ extended TAM, extended expectation confirmation model (E-ECM), integration of commitment-trust theory and UTAUT, as well as integration of ECM and technology readiness index (TRI) to explain users' intention to continue to use e-payments $[13,14,25,38,39]$.

The table summarizes the previous studies focusing on the scenarios related to the e-payments, core constructs, decisions, respondents and the theoretical foundation that have been employed to obtain the study findings. Despite the existence of numerous past studies focusing on the initial adoption, intention or continuous usage intention of e-payment, the e-transaction services in wholesale markets of agriproducts in China still need further study. The following remarks can better explain the unique features of our study compared to previous ones. First, the problem of usage intention to e-payments from the customers' (or consumers) perspective has been intensively investigated (Table 1). Limited studies are available on the usage intention from vendors' perspective. Second, existing studies have mainly examined issues related to mobile payments, Internet banking, e-payment in public transportation, e-payment in e-commerce, prepaid cards in the hospital industry and so on. As different e-payments are designed to interact with users in different scenarios, factors affecting users' continuous usage intention to a target e-payments may be different in various scenarios [6], such as e-transaction in agricultural wholesale markets, and have yet to be examined. Third, most of the related literature introduced security issues as new variables to explain the initial adoption and the continuous usage intention to e-payment. However, only few studies have divided security issues into different dimensions. This paper attempts to fill the existing gaps.

\section{E-transaction services in ZWMA at a glance}

ZWMA is located in Hefei, capital of Anhui Province, covering an area of 84 hectares, with a construction area of 1.1 million square meters. This is a large-scale integrated market that offers vegetables, fruits, fish and seafood, livestock, poultry, grain, edible oils, etc., and 4.4 million tons of products were sold in 2019 , ranking this market in the top 20 in China. ${ }^{5}$ These agriproducts are collected from across the country and supplied to approximately 20 million residents in and around Hefei. A state-owned firm holds all the fixed assets of the

\footnotetext{
${ }^{5}$ http://www.hfzgncp.com.cn/info.php?class_id=101 (in Chinese).
} 
Table 1 The overview of previous research works

\begin{tabular}{|c|c|c|c|c|c|c|}
\hline Author(s) & Year & Scenarios & $\begin{array}{l}\text { Theoretical } \\
\text { foundation }\end{array}$ & Core constructs & Decisions & Respondents \\
\hline Chen & 2008 & Mobile payment & TAM and DOI & $\begin{array}{l}\text { PEOU, PU, security } \\
\text { concerns, privacy } \\
\text { concerns, PR, } \\
\text { compatibility, etc. }\end{array}$ & Intention & Consumers \\
\hline Schierz et al. & 2010 & Mobile payment & Extended TAM & $\begin{array}{l}\text { PEOU, PU, PS, com- } \\
\text { patibility, subjec- } \\
\text { tive norm, etc. }\end{array}$ & Intention & Consumers \\
\hline Liébana-Cabanillas et al & 2018 & Mobile payment & Extended TAM & $\begin{array}{l}\text { PEOU, PU, PR, trust, } \\
\text { attitude, etc. }\end{array}$ & Intention & Customers \\
\hline Barkhordari et al. & 2017 & Internet banking & Trust theory & $\begin{array}{l}\text { PEOU, PU, PS, per- } \\
\text { ceived trust }\end{array}$ & Adoption & Banks' customers \\
\hline Alhassany and Faisal & 2018 & Internet banking & Extended TAM & $\begin{array}{l}\text { PEOU, PU, PR, sub- } \\
\text { jective norm, etc. }\end{array}$ & Adoption & $\begin{array}{l}\text { International } \\
\text { students }\end{array}$ \\
\hline Choi et al. & 2015 & Transportation card & E-ECM & $\begin{array}{l}\text { PEOU, product } \\
\text { attributes, service } \\
\text { quality, etc. }\end{array}$ & $\begin{array}{l}\text { Continuance } \\
\text { and intention }\end{array}$ & Customers \\
\hline He et al.. & 2007 & $\begin{array}{l}\text { Online payment in } \\
\text { e-commerce }\end{array}$ & Trust theory & $\begin{array}{l}\text { PR, PEOU, PU, } \\
\text { vendor's system } \\
\text { features, etc. }\end{array}$ & Adoption & Customers \\
\hline Namweli and Magali & 2018 & $\begin{array}{l}\text { E-payment cards in the } \\
\text { hospital industry }\end{array}$ & TAM & PEOU, PU, attitude & Adoption & $\begin{array}{l}\text { Customers (outpa- } \\
\text { tients) }\end{array}$ \\
\hline Yu & 2012 & Mobile banking & UTAUT & $\begin{array}{l}\text { PE, E E, social influ- } \\
\text { ence, perceived } \\
\text { credibility, etc. }\end{array}$ & Adoption & $\begin{array}{l}\text { Customers } \\
\text { (mobile banking } \\
\text { users) }\end{array}$ \\
\hline $\begin{array}{l}\text { Chaiyasoonthorn and } \\
\text { Suksa-ngiam }\end{array}$ & 2019 & E-payment & Extended UTAUT & $\begin{array}{l}\text { PE, EE, social influ- } \\
\text { ence, habit, etc. }\end{array}$ & Adoption & Customers \\
\hline Yang et al. & 2012 & Mobile payment & DOI & $\begin{array}{l}\text { RA, compatibility, } \\
\text { PR, perceived fee, } \\
\text { etc. }\end{array}$ & Adoption & $\begin{array}{l}\text { Customers (poten- } \\
\text { tial and current } \\
\text { users) }\end{array}$ \\
\hline Kapoor et al. & 2015 & $\begin{array}{l}\text { Interbank mobile pay- } \\
\text { ment }\end{array}$ & DOI & $\begin{array}{l}\text { RA, compatibility, } \\
\text { riskiness, etc. }\end{array}$ & Intention & $\begin{array}{l}\text { Customers } \\
\text { (adopters or } \\
\text { nonadopters) }\end{array}$ \\
\hline Ramos-De-Luna et al. & 2016 & Mobile payment & Extended TAM & $\begin{array}{l}\text { PEOU, PU, PS, per- } \\
\text { ceived compat- } \\
\text { ibility, etc. }\end{array}$ & Intention & Customers \\
\hline Oyelami et al. & 2020 & E-payment & Trust theory & $\begin{array}{l}\text { Convenience, secu- } \\
\text { rity and safety, } \\
\text { trust, etc. }\end{array}$ & Adoption & Consumers \\
\hline $\begin{array}{l}\text { Khedmatgozar and } \\
\text { Shahnazi }\end{array}$ & 2018 & Internet banking & PR theory & $\begin{array}{l}\text { Security risk, privacy } \\
\text { risk, time risk, } \\
\text { financial risks, etc. }\end{array}$ & Adoption & $\begin{array}{l}\text { Customers (corpo- } \\
\text { rate clients) }\end{array}$ \\
\hline Roussou et al. & 2019 & Digital currencies & $\begin{array}{l}\text { Innovation decision } \\
\text { process model and } \\
\text { TAM }\end{array}$ & $\begin{array}{l}\text { PEOU, PU, PS, com- } \\
\text { patibility, etc. }\end{array}$ & Adoption & Customers \\
\hline Tsai et al. & 2014 & Internet banking & Extended TAM & $\begin{array}{l}\text { PEOU, PU, per- } \\
\text { ceived compat- } \\
\text { ibility, etc. }\end{array}$ & $\begin{array}{l}\text { Continuous } \\
\text { intention }\end{array}$ & Banks' customers \\
\hline Humbani et al. & 2019 & Mobile payment & TRI and E-ECM & $\begin{array}{l}\text { PEOU, PU, satisfac- } \\
\text { tion }\end{array}$ & $\begin{array}{l}\text { Continuous } \\
\text { intention }\end{array}$ & Customers (users) \\
\hline Yuan et al. & 2019 & Internet banking & $\begin{array}{l}\text { Commitment trust } \\
\text { theory and UTAUT }\end{array}$ & $\begin{array}{l}\text { Trust, commitment, } \\
\text { satisfaction, etc. }\end{array}$ & $\begin{array}{l}\text { Continuous } \\
\text { intention }\end{array}$ & Target customers \\
\hline Asnakew & 2020 & Mobile banking & TAM and trust theory & $\begin{array}{l}\text { PEOU, PU, trust, } \\
\text { attitude, etc. }\end{array}$ & $\begin{array}{l}\text { Continuous } \\
\text { intention }\end{array}$ & Banks' customers \\
\hline
\end{tabular}


market and is responsible for operation. The firm's revenue comes from renting market assets and charging for providing services to traders. Generally, the traders are neither employees nor shareholders of the state-owned firm.

The e-transaction system in the ZWMA was completed in 2013. Users need to apply for a card when using the e-transaction services for the first time. There are two types of cards, buyer card and seller card, both of which can link to their bank accounts. Using e-transaction cards for transaction does not require a third party. The buyer and the seller can complete the transaction directly through the self-assistant terminal. The selfassistant terminal is an integrated electronic scale device with an e-transaction function, which is distributed at the traders' point-of-sale (a of Fig. 1). The flow diagram of using e-transaction cards is summarized in b of Fig. 1.

The e-transaction system can automatically upload the transaction data after a transaction is completed, including data on the item name, specifications, sales volume, unit price, turnover, provenance, next destination and the identity information of the buyer and seller. At present, the system can collect approximately 55,000 transaction data per day. Compared with traditional manual data collection, this method has the advantages of saving time and effort and can ensure data integrity, accuracy and timeliness. The Hefei Price Bureau successfully introduced the ZWMA Price Index based on mass transaction data and improved the information service capability of the government. Additionally, the e-transaction system could function as a traceability tool for ensuring food safety and quality. With this system, the end consumer can easily provide feedback on any quality problem; this system can also enable rapid recalls or withdrawals of defective products. Traders can benefit from a reduction in transaction costs and the increase in convenience when using e-transaction. Although the e-transaction service appears to have numerous benefits, the operation firm has encountered resistance when generalizing its use. The e-transaction service is currently widely used only for vegetable and meat transactions in ZWMA. Therefore, much more effort is needed to identify the factors influencing traders' continuous usage intention to e-transaction cards.

\section{Theoretical background and hypothesis}

Some scholars argued that initial adoption and the continuous usage intention to any new technology are influenced by different factors [40, 41]. Nevertheless, some scholars, such as Thong et al. [42], demonstrated that initial intention and continuous usage intention can be treated as equivalent constructs but measured at different time points. The users' continuous usage intention is dependent as much upon one's post-adoption perceptions after sufficient experience [42, 43]. Previous studies consider that TAM could be used to explain post-adoption phenomena, although it was not included in the original TAM model [44]. Bhattacherjee [44] and Thong et al. [42] proposed an E-ECM for understanding continuous usage intention to information technology by integrating expectation confirmation theory and TAM and theorizes that PEOU and PU are the two key determinants of individual continuous usage intention to information technology. Several previous empirical studies employ extended TAM to explain users' intention to continue use Internet banking and mobile payment apps $[25,38]$. Therefore, this study employs TAM as the theoretical basis and employs the classic variables PEOU and PU in the model.

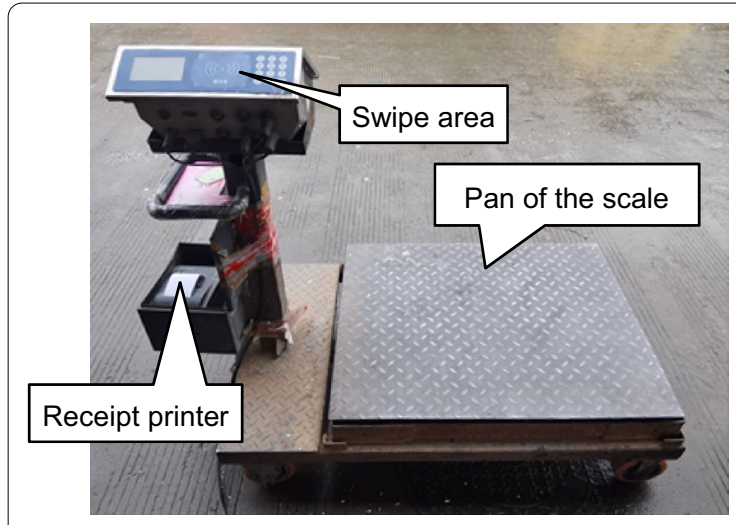

a

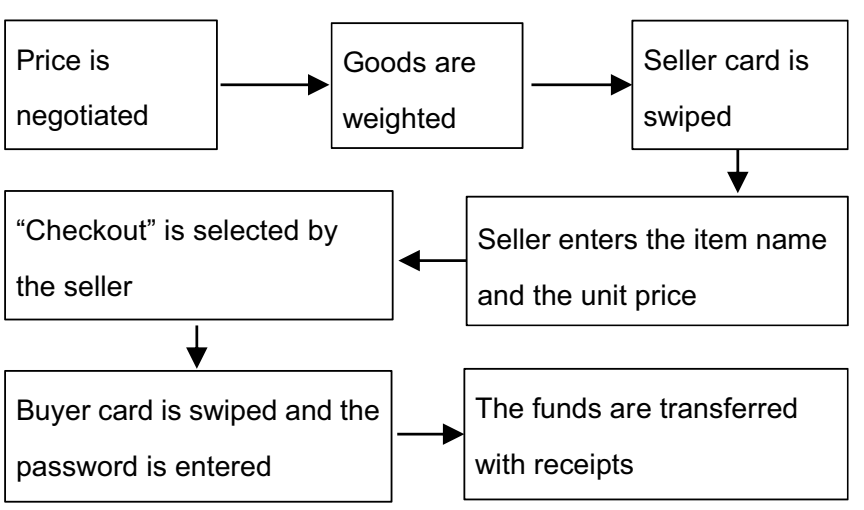

b

Fig. 1 The self-assistant terminal and flow diagram of using e-transaction cards 
There are additional reasons of choosing TAM model as the theoretical basis for this study. On the one hand, TAM is generally considered to be one of the most parsimonious, yet robust theoretical model, and has been extensively used to investigate initial adoption, intention or continuous intention of e-payments [38]. On the other hand, TAM has a very effective psychometric measurement method providing a quick and inexpensive approach to obtain general information about an individual's PU and PEOU of using a specific technology [45].

Choi et al. [14] and Tsai et al. [38] proposed that PEOU has an indirect effect on continuous usage intention through PU. Therefore, this study employs the classic variables PEOU and PU in the model to predict the continuous usage intention to e-transaction cards. Accordingly, we hypothesize that:

Hypothesis 1 PEOU affects positively on the continuous usage intention to e-transaction cards.

Hypothesis 2 PU affects positively on the continuous usage intention to e-transaction cards.

Hypothesis 3 PEOU affects positively on the PU of e-transaction services.

The original TAM focuses on PU and PEOU, which reflect the general perspective of usage intention to e-transaction cards. Recent research points out that the original TAM was a parsimonious model, so it should be extended by adding other variables particularly relevant to the technology being investigated [46, 47]. According to E-ECM, users' continuous usage intention to a technology is mainly determined by their postadoption perceptions of technology performance [43]. One of the reasons that customers hesitate to use the web for financial transactions is that they are afraid of issues related to risk and security [21, 22]. Perceived security is defined as the subjective evaluation of the security from the user's viewpoint [22, 48]. Therefore, subjective security can be regarded as the opposite reflection of perceived risk level [22]. It is unlikely that the average individual is able to objectively evaluate the security of an electronic payment process, but the essential condition for e-payment acceptance is the perception of security [22].

The e-transaction system using the Internet for financial transactions is associated with two types of security: (a) perceived transaction security represents a user's perception that the online transaction system will fulfill security requirements such as integrity, authentication, encryption and nonrepudiation [49]; and (b) perceived privacy security is defined as the degree of the perception that the e-payment system will provide security against secondary use and unauthorized access to the user's data when a user interacts with the e-transaction system [7, 48]. People care about security issues (both privacy and transaction security) very much when using the Internet for financial transactions $[7,35]$. In general, if the e-payment system can ensure the transactions are secure and maintain the privacy of user data, the voluntary acceptance of the system is likely to increase [7, 35]. Additionally, users perceive e-payment to be more useful when it can ensure the transactions are secure and the user data remains private [50]. Therefore, we propose the hypotheses as follows:

Hypothesis 4 Perceived transaction security affects positively on the continuous usage intention to e-transaction cards.

Hypothesis 5 Perceived privacy security affects positively on the continuous usage intention to e-transaction cards.

Hypothesis 6 Perceived transaction security affects positively on the PU of e-transaction services.

Hypothesis 7 Perceived privacy security affects positively on the PU of e-transaction services.

In Fig. 2, we summarize the proposed model according to the research hypotheses.

\section{Methods}

\section{Measurement of variables}

This study employs survey research as the primary methodology. A five-point Likert scale is used to develop a questionnaire to measure the relevant constructs. The study first involves a review of the literature, and then, a set of factors influencing PEOU, PU, perceived transaction security and perceived privacy security is identified. Reliability and validity of constructs are assessed through confirmatory factor analysis (CFA). Each construct in the questionnaire is measured by multiple indices, and many of which are derived from the existing literature; the wording of this questionnaire is modified to be in accord with the present context. Table 2 presents a list of all indices and their sources.

\section{Data collection}

In May 2018, we employed self-administered surveys for data collection in ZWMA. The reason of selecting ZWMA was that the trading volume of ZWMA ranks in the top 20 in China. This would ensure that 


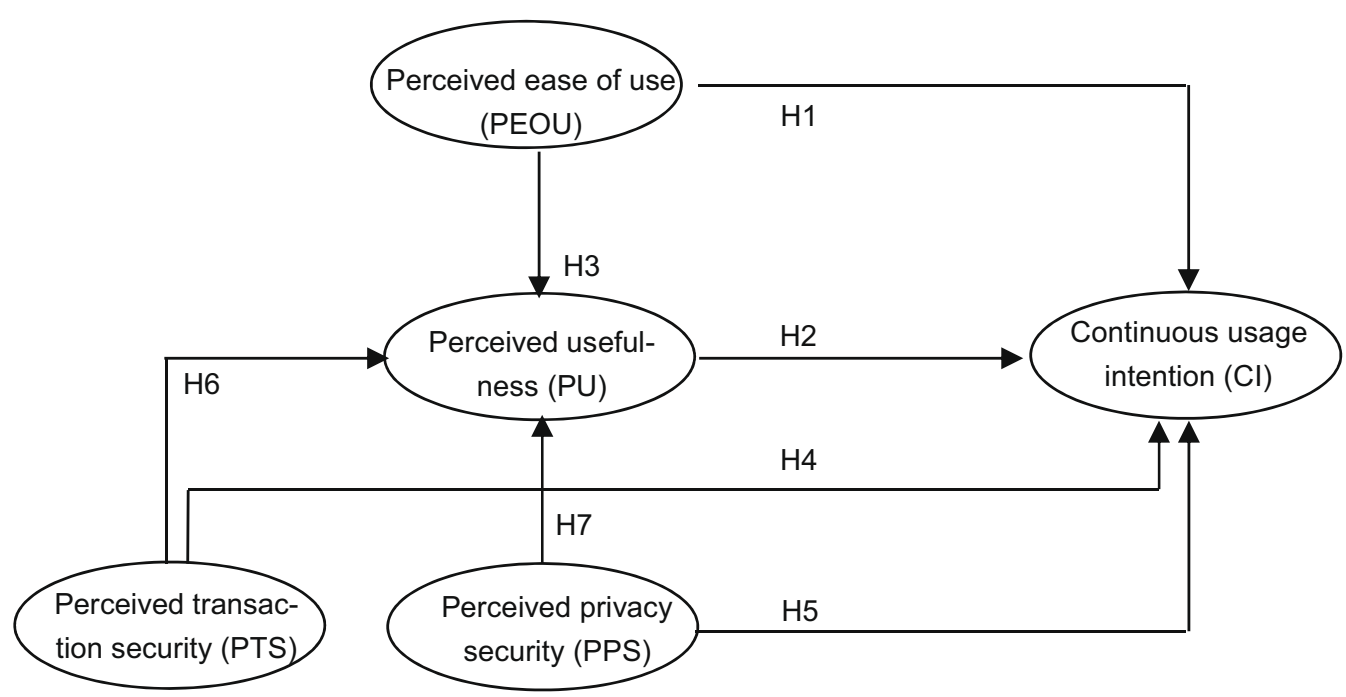

Fig. 2 Proposed research model for the continuous usage intention to e-transaction cards

we obtain representative data. Each respondent was asked to response the questionnaire carefully. Meanwhile, in order to ensure the respondents had enough background to answer the questions, the questionnaire was preceded by a brief introduction. For the purpose of ensuring adequate reliability of the data collection instruments, the questionnaire was reviewed by the peer group and modified according to the expert

Table 2 Measurement indices

\begin{tabular}{|c|c|c|}
\hline Construct & Indices & References \\
\hline \multirow[t]{3}{*}{ Perceived ease of use (PEOU) } & PEOU1: Learning to use e-transaction cards for transactions is easy & \multirow[t]{3}{*}[26,32,46]{} \\
\hline & $\begin{array}{l}\text { PEOU2: It is easy to follow all the steps to use e-transaction cards for making payments and accept- } \\
\text { ing payments }\end{array}$ & \\
\hline & $\begin{array}{l}\text { PEOU3: It is easy to follow all the steps to use e-transaction cards for prestoring, withdrawing, and } \\
\text { transferring funds }\end{array}$ & \\
\hline \multirow{3}{*}{$\begin{array}{l}\text { Perceived usefulness } \\
\text { (PU) }\end{array}$} & PU1: Using e-transaction cards makes the handling of payments easier and faster & \multirow[t]{3}{*}[8,26,46]{} \\
\hline & $\begin{array}{l}\text { PU2: Using e-transaction cards usually involves a transaction summary, which could improve my } \\
\text { business }\end{array}$ & \\
\hline & $\begin{array}{l}\text { PU3: Using e-transaction cards could avoid buyers refusing to pay with small change and thus } \\
\text { could increase my earnings (new measure) }\end{array}$ & \\
\hline \multirow[t]{3}{*}{ Perceived transaction security (PTS) } & $\begin{array}{l}\text { PTS1: Using e-transaction cards usually involves a transaction summary, which can assure me that } \\
\text { the transaction data remain intact and cannot be altered (integrity and nonrepudiation) }\end{array}$ & \multirow[t]{3}{*}[7,21,36]{} \\
\hline & $\begin{array}{l}\text { PTS2: I believe that the e-transaction system has security controls to prevent hacker invasions } \\
\text { (encryption) }\end{array}$ & \\
\hline & $\begin{array}{l}\text { PTS3: Using e-transaction cards usually involves needing to set and verify a password, so I believe } \\
\text { that the e-transaction system is restricted to legitimate users only (authentication and nonrepu- } \\
\text { diation) }\end{array}$ & \\
\hline \multirow[t]{3}{*}{ Perceived privacy security (PPS) } & $\begin{array}{l}\text { PPS 1: I do not believe that our transaction data will be released to the tax agency by the e-transac- } \\
\text { tion service providers }\end{array}$ & \multirow[t]{3}{*}[7,8,21,36]{} \\
\hline & $\begin{array}{l}\text { PPS 2: I do not believe that our transaction data will be released to business competitors by } \\
\text { e-transaction service providers }\end{array}$ & \\
\hline & $\begin{array}{l}\text { PPS 3: I do not believe that our transaction data will be used by the market authority to make } \\
\text { charges }\end{array}$ & \\
\hline \multirow[t]{2}{*}{$\begin{array}{l}\text { Continuous usage intention } \\
\text { (Cl) }\end{array}$} & $\begin{array}{l}\mathrm{Cl1} \text { :I will continue to use e-transaction cards for transactions, even if enforcement measures are not } \\
\text { taken by the market authority }\end{array}$ & \multirow[t]{2}{*}[8,21,50-52]{} \\
\hline & CI2: I recommended that other customers use e-transaction cards for transactions & \\
\hline
\end{tabular}


opinion. It is essential to determine the minimum required sample size for data collection. This paper used Cochran's method to determine the sample size [11].

$$
n=\frac{Z^{2} p(1-p)}{e^{2}}
$$

where $n$ is the minimum required sample size, $Z$ is the abscissa of the normal curve that cuts off an area $a$ at the tails, $e$ is the desired level of precision, $p$ is the estimated proportion of an attribute that is present in the population. In the current study, with the $95 \%$ confidence level, 0.5 maximum variability assumed of $P$, and $7 \%$ level of precision, the computed minimum required sample size is 196.

There are 9 trading areas in Zhougudui Vegetable Trading Center, and each trading area has approximately 200 fixed stores. Under the guidance of the staff of ZWMA, the researcher team distributed range from 30 to 35 paper-and-pencil questionnaires in each trading area by the simple random sampling method. In total, 300 copies of the survey questionnaire were randomly distributed to the traders, and 226 were collected. Of the collected copies, 22 were incompletely or not filled out properly. After dropping invalid questionnaire, a total of 204 responses were usable for data analysis, yielding an effective rate of $90 \%$. According to the mentioned descriptions, this sample size is satisfactory for performing confirmative factor analysis in current study.

Table 3 presents the descriptive statistics of the respondents. In terms of sample population of responses, $82.4 \%$ are males, and $17.6 \%$ are females. A total of $66.2 \%$ of the participants are between 30 and 49 years of age. Additionally, only $13.7 \%$ of the participants have a college degree or above, indicating that the traders have a

Table 3 Descriptive statistics of the respondents

\begin{tabular}{llcc}
\hline Criterion & Factor & Frequency & Percent \\
\hline Gender & Male & 168 & 82.4 \\
& Female & 36 & 17.6 \\
Age & 17-20 years & 5 & 2.5 \\
& 20-29 years & 53 & 26.0 \\
& 30-39 years & 81 & 39.7 \\
& 40-49 years & 54 & 26.5 \\
Education level & P0 years or over & 11 & 5.4 \\
& Middle school & 17 & 8.3 \\
& High school (secondary school) & 88 & 34.8 \\
& College degree or above & 28 & 13.1 \\
\hline
\end{tabular}

relatively low level of education. The composition of the sample can represent the whole population in ZWMA.

\section{Data analysis and results}

This study employs the two-step procedure presented by [53] for data analysis. First, in order to test the scale reliability and validity, we estimate the measurement model through CFA. Second, we apply SEM method to examine the overall model fit and test the proposed hypotheses. There are a series of latent variables in the proposed model, and each latent construct has a direct impact on the other constructs. One of the representative applications of structural model is to evaluate the proposed path coefficients when the proposed constructs are latent rather than observed [53]. Therefore, we employ the SEM to test the proposed hypotheses.

\section{Measurement model}

The present study analyzes the convergent validity, discriminant validity and the reliability of all the multipleitem scales according to the guidelines listed in [54]. The measurement values are presented in Table 4.

The present study evaluates the reliability in terms of composite reliability. As shown in Table 4, all values related to composite reliability (ranging from 0.794 to 0.926) are above the recommended cutoff of 0.70 [54, 55], indicating acceptable reliability. As shown in Table 4, 12 item loadings are greater than the goods scale 0.70 (except those for items PU3 and PT3, which are greater than the minimum cutoff of 0.50 ). In addition, all the AVEs (ranging from 0.562 to 0.862 ) are higher than the construct level of 0.50 [54], indicating adequate convergent validity of the constructs. We evaluate the discriminant validity through comparing the square root of the AVE of each construct with the corresponding inter-construct correlation values. As shown in Table 5, all square roots of the AVEs on the diagonal are higher than the corresponding inter-construct correlation values (below diagonals), which demonstrated adequate discriminant validity of the model.

\section{Structural model}

In order to enhance the fitness of the structural equation, we modify the model by establishing the covariance between latent variables [27]. We employ a combination of fitness indices to assess the fitness of the model. As shown in Table 6, the fitness indices are root-meansquare error approximation (RMSEA) $=0.071$, goodness of fit index $(\mathrm{GFI})=0.917$, normalized fit index $(\mathrm{NFI})=0.923$, incremental fit index $\quad(\mathrm{IFI})=0.959$, Tucker Lewis index $(\mathrm{TLI})=0.944$, comparative fit index $(\mathrm{CFI})=0.959$, parsimony unbiased goodness of fit 
Table 4 Results of the factor loadings, validity and reliability

\begin{tabular}{|c|c|c|c|c|c|c|}
\hline Construct (latent variable) & Indicators & Loadings & $\begin{array}{l}\text { Indicator } \\
\text { reliability } \\
\text { (loadings2) }\end{array}$ & Standard error & $\begin{array}{l}\text { Composite } \\
\text { reliability (CR) }\end{array}$ & $\begin{array}{l}\text { Average } \\
\text { variance } \\
\text { extracted (AVE) }\end{array}$ \\
\hline \multirow[t]{3}{*}{ Perceived ease of use (PEOU) } & PEOU 1 & 0.868 & 0.753 & 0.247 & 0.917 & 0.788 \\
\hline & PEOU 2 & 0.758 & 0.575 & 0.425 & & \\
\hline & PEOU 3 & 0.815 & 0.664 & 0.336 & & \\
\hline \multirow[t]{3}{*}{ Perceived usefulness (PU) } & PU 1 & 0.844 & 0.712 & 0.288 & 0.860 & 0.674 \\
\hline & PU 2 & 0.778 & 0.605 & 0.395 & & \\
\hline & PU 3 & 0.650 & 0.423 & 0.578 & & \\
\hline \multirow[t]{3}{*}{ Perceived transaction security (PTS) } & PTS 1 & 0.797 & 0.635 & 0.365 & 0.860 & 0.681 \\
\hline & PTS2 & 0.921 & 0.848 & 0.152 & & \\
\hline & PTS 3 & 0.561 & 0.315 & 0.685 & & \\
\hline \multirow[t]{3}{*}{ Perceived privacy security (PPS) } & PPS 1 & 0.787 & 0.619 & 0.381 & 0.794 & 0.562 \\
\hline & PPS 2 & 0.787 & 0.619 & 0.381 & & \\
\hline & PPS 3 & 0.812 & 0.659 & 0.341 & & \\
\hline \multirow[t]{2}{*}{ Continuous usage intention (Cl) } & UI 1 & 0.913 & 0.834 & 0.166 & 0.926 & 0.862 \\
\hline & UI 2 & 0.916 & 0.839 & 0.161 & & \\
\hline
\end{tabular}

Table 5 Correlations between constructs

\begin{tabular}{|c|c|c|c|c|c|}
\hline Construct (latent variable) & $\begin{array}{l}\text { Perceived ease } \\
\text { of use (PEOU) }\end{array}$ & $\begin{array}{l}\text { Perceived } \\
\text { usefulness (PU) }\end{array}$ & $\begin{array}{l}\text { Perceived transaction } \\
\text { security (PTS) }\end{array}$ & $\begin{array}{l}\text { Perceived privacy } \\
\text { security (PPS) }\end{array}$ & $\begin{array}{l}\text { Continuous } \\
\text { usage intention } \\
\text { (UI) }\end{array}$ \\
\hline Perceived ease of use (PEOU) & 0.888 & & & & \\
\hline Perceived usefulness (PU) & 0.710 & 0.821 & & & \\
\hline Perceived transaction security (PTS) & 0.492 & 0.495 & 0.825 & & \\
\hline Perceived privacy security (PPS) & 0.571 & 0.406 & 0.749 & 0.750 & \\
\hline Continuous usage intention (CI) & 0.735 & 0.718 & 0.533 & 0.617 & 0.929 \\
\hline
\end{tabular}

The diagonals show the square roots of the AVEs. Values below diagonals are the inter-construct correlation values

Table 6 Fitness indices for the proposed model

\begin{tabular}{|c|c|c|c|c|c|c|c|c|c|}
\hline Fitness indices & RMSEA & GFI & NFI & IFI & TLI & CFI & PGFI & PNFI & $x^{2} / d f$ \\
\hline Acceptable values & $0.05-0.08$ & $>0.90$ & $>0.90$ & $>0.90$ & $>0.90$ & $>0.90$ & $>0.50$ & $>0.50$ & $<3$ \\
\hline Calculated values & 0.071 & 0.917 & 0.923 & 0.959 & 0.944 & 0.959 & 0.585 & 0.679 & 2.032 \\
\hline
\end{tabular}

index $(\mathrm{PGFI})=0.585$, parsimonious normed fit index $(\mathrm{PNFI})=0.679$, and Chi-square/degrees of freedom ratio $\left(\chi^{2} / d f\right)=2.032$. According to [56-58], all the calculated values of fitness indices are shown an acceptable levels, thus suggesting that the proposed model fits very well with the collected data.

Figure 3 shows the assessment results of the measurement-validation and hypothesis-path testing using the AMOS 22.0 software program. Accordingly, Table 7 shows the summary of hypothesis-path results. As shown in Table 7, PEOU and PU affect positively on continuous usage intention with standardized path coefficients of 0.280 and 0.413 , respectively, confirming $\mathrm{H} 1$ and $\mathrm{H} 2$. PEOU has a significant positive effect on the PU with a standardized path coefficient of 0.678 ; thus, $\mathrm{H} 3$ is supported. Multiplying the coefficients along the paths [48], the total effect of PEOU on continuous usage intention is $0.56\left(=0.280+0.678^{*} 0.413\right)$. Furthermore, perceived privacy security is observed to have a direct positive effect on continuous usage intention with a standardized path coefficient of 0.33 ; thus, H5 is supported. An unexpected result is that the PTS shows a nonsignificant direct relationship with continuous usage intention, and 


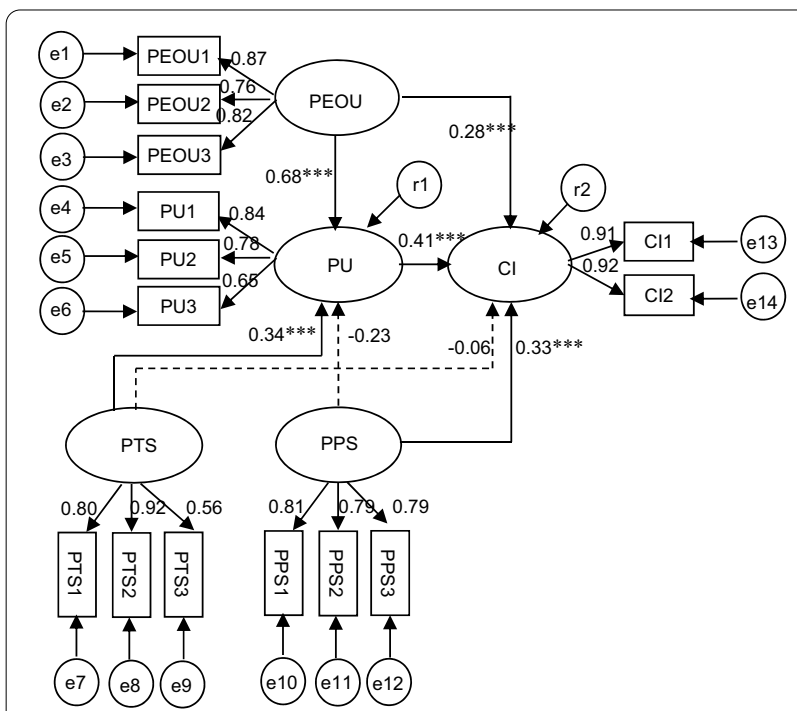

Fig. 3 Structural model results. Note:***suggests that correlation is significant at the 0.01 level

thus H4 is rejected. Instead, PTS significantly affects the PU with a standardized path coefficient of 0.337; thus, H6 is supported. Therefore, PTS has an indirect positive effect of $0.137(=0.337 * 0.413)$ on continuous usage intention. In addition, it is found that the PPS shows a nonsignificant effect on PU; thus, $\mathrm{H} 7$ is not supported. In summary, the standardized path coefficients of $\mathrm{H} 1, \mathrm{H} 2$, $\mathrm{H} 3, \mathrm{H} 5$ and $\mathrm{H} 6$ show a significant level of $p<0.01$. Therefore, $\mathrm{H} 1, \mathrm{H} 2, \mathrm{H} 3, \mathrm{H} 5$ and $\mathrm{H} 6$ are supported, while $\mathrm{H} 4$ and $\mathrm{H} 7$ are rejected.

\section{Conclusion}

Research contribution, discussion and implications

This paper employs the classic variables PEOU and PU of TAM, combining perceived transaction security and perceived privacy security as additional constructs to explain the factors affecting traders' continuous usage intention to e-transaction cards in wholesale markets of agriproducts in China. Our findings show that the classic variables
PEOU and PU are still valid for explaining the continuous usage intention to e-transaction cards in wholesale markets of agriproducts in China. The findings indicate that PEOU and PU have direct and positive influence on traders' continuous usage intention, in line with [25]. Moreover, PEOU has an indirect effect on the continuous usage intention to e-transaction cards through PU. Our findings are not entirely consistent with previous studies. For example, Tsai et al. [38] reported that PU appears to have a direct and positive impact on users' continuous usage intention to Internet banking; however, PEOU only indirectly affects the continuous usage intention through PU. As indicated by [39], in terms of predicting the intention to continue to use mobile payment apps, PU did not reach the level of significance, while PEOU, although significant, showed an inverse relationship that is contrary to our findings. A plausible explanation could be the fact that effects of PEOU and PU on users' usage intention to a target e-payment may be different in various scenarios, thereby highlighting the importance of this research.

This paper identifies the effects of different dimensions of PS. The findings show that traders' PPS directly and positively affects traders' continuous usage intention, in line with $[7,35]$. Contrary to what is assumed, the PTS shows a nonsignificant direct relationship with continuous usage intention, which is not consistent with the results of $[7,35]$. The different role of PPS and PTS indicates that dividing PS into two dimensions is of great value. A numerous past studies empirically suggested that the overall PS (or overall PR) significantly related to the intention or adoption of the e-payment $[8,10,12$, 23]. Nevertheless, it could not accurately to conclude that both transaction security concerns and privacy concerns are related to the success or failure of usage intention or adoption.

One possible and reasonable explanation of nonsignificant effect of PTS is the high penetration rate of third-party online payments (i.e., Wepay and Alipay) in China. According to the report published by the Statista

\section{Table 7 Results of testing the hypotheses with the research model}

\begin{tabular}{|c|c|c|c|c|}
\hline Hypothesized path & $\begin{array}{l}\text { Standardized } \\
\text { coefficients }\end{array}$ & C.R & $p$ value & Remarks \\
\hline H1: Perceived ease of use $\rightarrow$ continuous usage intention & 0.280 & 2.697 & $0.007^{* * *}$ & Supported \\
\hline H2: Perceived usefulness $\rightarrow$ continuous usage intention & 0.413 & 3.974 & $0.000^{* * *}$ & Supported \\
\hline H3: Perceived ease of use $\rightarrow$ perceived usefulness & 0.678 & 6.229 & $0.000^{* * *}$ & Supported \\
\hline H4: Perceived transaction security $\rightarrow$ continuous usage intention & -0.059 & -0.581 & 0.561 & Rejected \\
\hline H5: Perceived privacy security $\rightarrow$ continuous usage intention & 0.334 & 3.003 & $0.003^{* * *}$ & Supported \\
\hline H6: Perceived transaction security $\rightarrow$ perceived usefulness & 0.337 & 2.714 & $0.007^{* * *}$ & Supported \\
\hline H7: Perceived privacy security $\rightarrow$ perceived usefulness & -0.234 & -1.782 & 0.075 & Rejected \\
\hline
\end{tabular}

***Suggests that the standardized path coefficient is significant at the 0.01 level 
Research Department, approximately $72.5 \%$ of Internet users in China used online payment services by the end of 2018. ${ }^{6}$ The majority of users rarely experienced transaction errors or financial losses when they used third-party online payments. This experience will enhance users' trust in the transaction security of other e-payment services, such as the e-transaction system used in wholesale markets. Therefore, PTS may not be a major concern for traders' continuous usage of e-transaction cards. In contrast, the transaction data collected by the e-transaction systems include data on the goods' provenance, discriminatory prices offered to different purchasers and transaction volume, which are important commercial secrets of traders. Therefore, compared to consumers, traders may be more worried about transaction data leaks. However, PTS positively and indirectly affects continuous usage intention through PU.

The study not only contributes to new theoretical findings of studying continuance intention in e-payment but also has important practical implications. Considering the large investment in e-transaction systems in wholesale markets of agriproducts in China, it is essential to ensure that traders will actually continue to use them. To achieve this goal, the first practical implication is that, instead of only enhancing the benefits for e-transaction service providers (i.e., the data collection target of the government and administrative convenience for the operation firm), the e-transaction services ought to be trader-oriented. In order to enhance the PEOU of traders, the operation firm should ensure that the traders have easy access to usage training. Furthermore, our findings also suggest that attention must be given to designing easy-to-use and useful e-transaction systems for traders. The results also indicate that privacy security is one of the fundamental factors directly linked with continuous usage intention, but transaction security is not. Therefore, e-transaction service providers should allay the privacy concerns of traders.

\section{Research limitation and future research directions}

Although the present study provided some theoretical findings and practical implications of vendors' usage to e-transaction cards in wholesale markets of agriproducts, considerations have to be taken with regard to its limitations. First, due to limited resources and time, the study is based only on data collected from the ZWMA in Hefei. Thus, the conclusions drawn from this sample may not be highly representative of all the agricultural wholesale markets in China. Therefore, future researchers may consider a larger sample size than the present study and examine whether there are deviations from the results of present study. Second, we did not incorporate actual continuous usage behavior in the proposed model. Since the differences between intention and real behavior, the future research model should incorporate actual continuous usage of the e-transaction card, and to verify the relationship between intention to use and real usage behavior. Third, other factors that significantly affect vendors' continuous usage intention to e-transaction cards may exist. Also this study lacked the mediation analysis, which means that our study not integrated. Future research should develop a complete model to test the mediating role of attitude toward continuance intention and take into social and individual factors and so on.

\begin{abstract}
Abbreviations
AVE: Average variance extracted; CFA: Confirmatory factor analysis; CFI: Comparative fit index; $\mathrm{Cl}$ : Continuous usage intention; CR: Composite reliability; DOI: The diffusion of innovations; EE: Effort expectancy; GFI: Goodness of fit index; IFI: Incremental fit index; NFI: Normalized fit index; PE: Performance expectancy; PEOU: Perceived ease of use; PGFI: Parsimony unbiased goodness of fit index; PNFI: Parsimonious normed fit index; PPS: Perceived privacy security; PR: Perceived risk; PS: Perceived security; PTS: Perceived transaction security; PU: Perceived usefulness; RA: Relative advantage; RMSEA: Room-mean-square error approximation; SEM: Structural equation modeling; TAM: Technology acceptance model; TLI:Tucker Lewis index; TRA: Theory of reasoned action; TRI: Technology readiness index; UTAUT: Unified theory of acceptance and use of technology; ZWMA: Zhougudui wholesale market of agriproducts.
\end{abstract}

\section{Acknowledgements}

Not applicable.

\section{Authors' contributions}

XCS proposed the subject, drafted the introduction, reviewed the literature, collected the data and analyzed the results. XHG highlighted the results, participated actively in statistical analysis and policy implications discussion. Both the authors read and approved the final version of the manuscript.

\section{Funding}

This work has been supported by Industry-Academia-Research Funds for the Doctoral Program of Hefei University of Technology (XC2016JZBZ22) and The Jiangsu Social Science Fund Key Project (K0201900192).

\section{Availability of data and materials}

The datasets on which the conclusions of the manuscript rely on are available upon request.

\section{Competing interests}

The authors declare that they have no competing interests.

\section{Author details}

${ }^{1}$ School of Economics, Hefei University of Technology, No. 485 Danxia Road, Hefei 230601, Anhui, People's Republic of China. ${ }^{2}$ College of Economics and Management, Nanjing Agricultural University, No. 1 Weigang, Nanjing 210095, Jiangsu, People's Republic of China.

Received: 12 August 2020 Accepted: 10 February 2021 Published: 11 March 2021

\section{References}

1. Ma ZJ, Xu ZY, Na SP (2011) The evolution in transaction technology on China's agriculture product wholesale market based on incentive 
compatibility perspective. J Beijing Tech Univ (SocSci) 26(6):1-8. https:// doi.org/10.16299/j.1009-6116.2011.06.003

2. Li Z, Yu X, Zeng Y, Holst R (2012) Estimating transport costs and trade barriers in China: direct evidence from Chinese agricultural traders. Chin Econ Rew 23(4):1003-1010. https://doi.org/10.1016/J.CHIECO.2012.05.001

3. Chen XL, Zhang Z, Zhang XC (2019) Study on the upgrading model and path of China's agricultural product wholesale market-the experiences from five common operation principles of world agricultural product wholesale market. Chin Bus Mark 33(2):30-37. https://doi.org/10.14089 /j.cnki.cn11-3664/f.2019.02.004

4. Ma ZJ (2015) The review of the development of China's agriculture wholesale market during the past 30 years and the outlook. Chin Bus Mark 29(05):11-16. https://doi.org/10.14089/j.cnki. cn11-3664/f.2015.05.002

5. Wang XJ (2015) Reform and innovation of wholesale-oriented vegetable circulation channels. Res Econ Manag 36(5):62-67

6. Dahlberg T, Guo J, Ondrus J (2015) A critical review of mobile payment research. Electron Commer Res Appl 14(5):265-284. https://doi. org/10.1016/j.elerap.2015.07.006

7. Chen L (2008) A model of consumer acceptance of mobile payment. Int J Mob Commun 6(1):32-52. https://doi.org/10.1504/IJMC.2008.015997

8. Schierz PG, Schilke O, Wirtz BW (2010) Understanding consumer acceptance of mobile payment services: an empirical analysis. Electron Commer Res Appl 9(3):209-216. https://doi.org/10.1016/J.ELERAP.2009.07.005

9. Slade EL, Dwivedi YK, Piercy NC, Williams MD (2015) Modeling consumers' adoption intentions of remote mobile payments in the United Kingdom: extending UTAUT with innovativeness, risk, and trust. Psychol Mark 32(8):860-873. https://doi.org/10.1002/MAR.20823

10. Liébana-Cabanillas F, Muñoz-Leiva F, Sánchez-Fernández J (2018) A global approach to the analysis of user behavior in mobile payment systems in the new electronic environment. Serv Bus 12(1):25-64. https://doi. org/10.1007/S11628-017-0336-7

11. Barkhordari M, Nourollah Z, Mashayekhi H, Mashayekhi Y, Ahangar MS (2017) Factors influencing adoption of e-payment systems: an empirical study on Iranian customers. InfSyst E-Bus Manag 15(1):89-116. https:// doi.org/10.1007/S10257-016-0311-1

12. Alhassany H, Faisal F (2018) Factors influencing the internet banking adoption decision in North Cyprus: an evidence from the partial least square approach of the structural equation modeling. FinancInnov 4(1):1-21. https://doi.org/10.1186/S40854-018-0111-3

13. Yuan Y, Lai F, Chu Z (2019) Continuous usage intention of Internet banking: a commitment-trust model. InfSyst E-Bus Manag 17(1):1-25. https:// doi.org/10.1007/S10257-018-0372-4

14. Choi M, Han K, Choi J (2015) The effects of product attributes and service quality of transportation card solutions on service user's continuance and word-of-mouth intention. Serv Bus 9:463-490. https://doi.org/10.1007/ S11628-014-0235-0

15. Lubanga JM, Gakobo T, Ochieng I, Kimando LN (2017) Factors influencing adoption of e-payment system in Kenyan public transport: a case of matatu plying Nairobi-Kitengela route. IntAcad J Hum Resour Bus Admin 2(4):27-48

16. He F, Mykytyn PP (2007) Decision factors for the adoption of an online payment system by customers. Int J E-Bus Res 3(4):1-32. https://doi. org/10.4018/JEBR.2007100101

17. Hove LV, Karimov FP (2016) The role of risk in e-retailers' adoption of payment methods: evidence for transition economies. Electron Commer Res 16(1):27-72. https://doi.org/10.1007/S10660-015-9203-6

18. Cardoso S, Martinez LF (2019) Online payments strategy: how third-party internet seals of approval and payment provider reputation influence the Millennials' online transactions. Electron Commer Res 19(1):189-209. https://doi.org/10.1007/S10660-018-9295-X

19. Namweli H, Magali J (2018) Factors affecting adoption of prepaid electronic payment cards in Tanzania: the case study of Kilimanjaro Christian Medical Centre (KCMC). Pan-Afr J Bus Manag 2(1):1-14

20. Chen JK (2018) The influence of behavioural intention on third-party e-commerce payment. S Afr J Econ ManagSci 21(1):a2157. https://doi. org/10.4102/sajems.v21i1.2157

21 Tsiakis T, Sthephanides G (2005) The concept of security and trust in electronic payments. Comput Secur 24(1):10-15

22. Linck K, Pousttchi K, Wiedemann DG (2006) Security issues in mobile payment from the customer viewpoint. Paper presented at the proceedings of the 14th European conference on information systems (ECIS 2006), Göteborg, Schweden, 12-14 June 2006, pp 1-11. https://aisel.aisnet.org/ ecis2006/62/. Accessed Aug 2020

23. Roussou I, Stiakakis E, Sifaleras A (2019) An empirical study on the commercial adoption of digital currencies. InfSyst E-Bus Manag 17(2):223-259. https://doi.org/10.1007/S10257-019-00426-7

24. Mitchell VM (2001) Re-conceptualizing consumer store image processing using perceived risk. J Bus Res 54(2):167-172. https://doi.org/10.1016/ S0148-2963(99)00086-7

25. Asnakew ZS (2020) Customers' continuance intention to use mobile banking: development and testing of an integrated model. Rev SocionetwStrateg 14:123-146. https://doi.org/10.1007/s12626-020-00060-7

26. Davis FD (1989) Perceived usefulness, perceived ease of use, and user acceptance of information technology. MIS Q 13(3):319-340. https://doi. org $/ 10.2307 / 249008$

27. Yu C-S (2012) Factors affecting individuals to adopt mobile banking: empirical evidence from the UTAUT model. J Electron Commer Res 13(2):104-121

28. Chaiyasoonthorn W, Suksa-ngiam W (2019) The diffusion and adoption of electronic payment systems in Bangkok. Int J E-Bus Res 15(2):102-115. https://doi.org/10.4018/IJEBR.2019040106

29. Lu Y, Yang S, Chau PY, Cao Y (2011) Dynamics between the trust transfer process and intention to use mobile payment services: a cross-environment perspective. InfManag 48(8):393-403. https://doi.org/10.1016/J. IM.2011.09.006

30. Yang S, Lu Y, Gupta S, Cao Y, Zhang R (2012) Mobile payment services adoption across time: an empirical study of the effects of behavioral beliefs, social influences, and personal traits. Comput Hum Behav 28(1):129-142. https://doi.org/10.1016/J.CHB.2011.08.019

31. Kapoor KK, Dwivedi YK, Williams MD (2015) Examining the role of three sets of innovation attributes for determining adoption of the interbank mobile payment service. InfSyst Front 17(5):1039-1056. https://doi. org/10.1007/S10796-014-9484-7

32. Ramos-de-Luna I, Montoro-Ríos F, Liébana-Cabanillas F (2016) Determinants of the intention to use NFC technology as a payment system: an acceptance model approach. InfSyst E-Bus Manag 14(2):293-314. https:// doi.org/10.1007/S10257-015-0284-5

33. Oyelami LO, Adebiyi SO, Adekunle BS (2020) Electronic payment adoption and consumers' spending growth: empirical evidence from Nigeria. Future Bus J 6:14. https://doi.org/10.1186/s43093-020-00022-z

34. Cho J (2004) Likelihood to abort an online transaction: influences from cognitive evaluations, attitudes, and behavioral variables. InfManag 41 (7):827-838. https://doi.org/10.1016/j.im.2003.08.013

35. Khedmatgozar HR, Shahnazi A (2018) The role of dimensions of perceived risk in adoption of corporate internet banking by customers in Iran. Electron Commer Res 18(2):389-412. https://doi.org/10.1007/S1066 0-017-9253-Z

36. Kim C, Tao W, Shin N, Kim K-S (2010) An empirical study of customers' perceptions of security and trust in e-payment systems. Electron Commer Res Appl 9(1):84-95. https://doi.org/10.1016/J.ELERAP.2009.04.014

37. Oney E, Guven GO, Rizvi WH (2017) The determinants of electronic payment systems usage from consumers' perspective. Econ Res 30(1):394415. https://doi.org/10.1080/1331677X.2017.1305791

38. Tsai HT, Chien JL, Tsai MT (2014) The influences of system usability and user satisfaction on continued Internet banking services usage intention: empirical evidence from Taiwan. Electron Commer Res 14:137-169. https ://doi.org/10.1007/s10660-014-9136-5

39. Humbani M, Wiese M, Humbani M, Wiese M (2019) An integrated framework for the adoption and continuance intention to use mobile payment apps. Int J Bank Mark 37(2):646-664. https://doi.org/10.1108/ IJBM-03-2018-0072

40. Eriksson K, Nilsson D (2007) Determinants of the continued use of self-service technology: the case of internet banking. Technovation 27(4):159-167. https://doi.org/10.1016/j.technovation.2006.11.001

41. Schuster L, Proudfoot J, Drennan J (2015) Understanding consumer loyalty to technology-based self-services with credence qualities. J Serv Mark 29(6):522-532. https://doi.org/10.1108/jsm-01-2015-0021

42. Thong JYL, Hong SJ, Tam KY (2006) The effects of post-adoption beliefs on the expectation-disconfirmation model of information technology continuance. Int J Hum Comput Stud 64(9):799-810. https://doi. org/10.1016/j.jijcs.2006.05.001 
43. Kim B (2012) The diffusion of mobile data services and applications: exploring the role of habit and its antecedents. Telecommun Policy 36(1):69-81. https://doi.org/10.1016/j.telpol.2011.11.011

44. Bhattacherjee $A$ (2001) Understanding information systems' continuance: an expectation-confirmation model. MIS Q 25(3):351-370. https://doi. org/10.2307/3250921

45. Mathieson K (1991) Predicting user intentions: comparing the technology acceptance model with the theory of planned behaviour. InfSystResh 2(3):173-191. https://doi.org/10.1080/0144929X.2016.1208773

46. Venkatesh V, Davis FD (2000) A theoretical extension of the technology acceptance model: four longitudinal field studies. ManagSci 46(2):186204. https://doi.org/10.1287/MNSC.46.2.186.11926

47. Moon J-W, Kim Y-G (2001) Extending the TAM for a World-Wide-Web context. InfManag 38(4):217-230. https://doi.org/10.1016/S0378 $-7206(00) 00061-6$

48. Wang YS, Wang YM, Lin HH, Tang $T$ (2003) Determinants of user acceptance of internet banking: an empirical study. Int J ServIndManag 14(5):501-519. https://doi.org/10.1108/09564230310500192

49 Kim DJ, Ferrin DL, Rao HR (2008) A trust-based consumer decisionmaking model in electronic commerce: the role of trust, perceived risk, and their antecedents. Decis Support Syst 44(2):544-564. https://doi. org/10.1016/J.DSS.2007.07.001

50. Cho H, Fiorito SS (2009) Acceptance of online customization for apparel shopping. Int J Retail DistribManag 37(5):389-407. https://doi. org/10.1108/09590550910954892

51. Venkatesh V, Morris MG, Davis GB, Davis FD (2003) User acceptance of information technology: toward a unified view. MIS Q 27(3):425-478. https://doi.org/10.2307/30036540

52. Junadi S (2015) A model of factors influencing consumer's intention to use e-payment system in Indonesia. ProcComputSci 59(1):214-220. https ://doi.org/10.1016/J.PROCS.2015.07.557
53. Anderson JC, Gerbing DW (1988) Structural equation modeling in practice: a review and recommended two-step approach. Psychol Bull 103(3):411-423. https://doi.org/10.1037/0033-2909.103.3.411

54. Fornell C, Larcker DF (1981) Evaluating structural equation models with unobservable variables and measurement error. J Mark Res 18(1):39-50. https://doi.org/10.2307/3151312

55. Nunnally JC, Bernstein IH (eds) (1994) Psychometric theory. McGraw-Hill, New York

56. Hu L, Bentler PM (1999) Cutoff criteria for fit indexes in covariance structure analysis: conventional criteria versus new alternatives. StructEqu Model 6(1):1-55. https://doi.org/10.1080/10705519909540118

57. Hooper D, Coughlan J, Mullen MR (2008) Structural equation modelling: guidelines for determining model fit. Electron J Bus Res Methods 6(1):53-60. https://doi.org/10.21427/D7CF7R

58. lacobucci D (2010) Structural equations modeling: fit indices, sample size, and advanced topics. J ConsumPsychol 20(1):90-98. https://doi. org/10.1016/J.JCPS.2009.09.003

\section{Publisher's Note}

Springer Nature remains neutral with regard to jurisdictional claims in published maps and institutional affiliations.

\section{Submit your manuscript to a SpringerOpen ${ }^{\circ}$ journal and benefit from:}

- Convenient online submission

- Rigorous peer review

- Open access: articles freely available online

- High visibility within the field

- Retaining the copyright to your article

Submit your next manuscript at $\boldsymbol{\nabla}$ springeropen.com 